\title{
Percepção de celebridades do esporte: um modelo de escolha, gestão e controle do seu uso em relação às marceas
}

\author{
Perception of sports celebrities: a model of choice, \\ management and control of their use in relation to brands
}

\author{
Percepción de celebridades del deporte: un modelo \\ de elección, gestión y control de su uso con \\ relación a las marcas
}

\section{Otávio Freire}

- Professor do Programa de Mestrado e Doutorado em Administração da Universidade Nove de Julho (PDMA-Uninove)

- Professor do Curso de Marketing da Escola de Artes, Ciências e Humanidades da Universidade de São Paulo (EACH-USP)

- Doutor em Ciências da Comunicação pela Escola de Comunicações e Artes da Universidade de São Paulo (ECA-USP)

- Coordenador-assistente e pesquisador do Centro de Estudos de Avaliação e Mensuração em Comunicação e Marketing da Universidade de São Paulo (Ceacom/ECA-USP)

- Diretor da llumeo Marketing e Comunicação

- otfreire@usp.br; otavioblf@uninove.br

\section{Diego Senise}

- Pesquisador em retorno de investimentos em comunicação, marcas e endosso de celebridades

- Bacharel em Publicidade e Propaganda pela Escola de Comunicações e Artes da Universidade de São Paulo (ECA-USP)

- Graduando em Ciências Sociais pela Faculdade de Filosofia, Letras e Ciências Humanas da Universidade de São Paulo (FFLCH-USP)

- Diretor da llumeo Marketing e Comunicação.

- senise@ilumeobrasil.com.br 
Resumo

Este artigo propõe um framework para gestão do uso de celebridades, com o intuito de minimizar riscos e otimizar resultados relativos ao processo de escolha e uso de celebridades endossantes. Apresentam-se uma revisão de literatura nacional e internacional relevante para o propósito do artigo, bem como dados quantitativos exploratórios coletados de 4,5 mil brasileiros, acerca da percepção de celebridades endossantes em uma série de atributos. As descobertas evidenciam diferenças de percepção dos grupos de celebridades analisados - geral, esportes e futebol (como subgrupo esportivo) -, indicando a necessidade de desenvolvimento e adoção de modelos de decisão sobre o uso de endosso de celebridades.

PALVRAS-CHAVE: ESPORTE • ENDOSSO DE CELEBRIDADES - MARCA ENDOSSADA • MARKETING • COMUNICAÇÃO

\section{Abstract}

This article proposes a celebrity endorsement management framework, developed to minimize the risks and optimize the results obtained by the use of a celebrity endorser. A national and international literature review is presented, as well as quantitative data gathered from among 4.5 thousand Brazilian citizens concerning their perceptions of endorsing celebrities in a number of attributes. The results show different perceptions about each group analyzed - general, sports and soccer (as a sports subgroup) - indicating the need for development and adoption celebrity endorsement management models.

KEYWORDS: SPORTS • ENDORSING OF CELEBRITIES • ENDORSED BRAND • MARKETING • COMMUNICATION

Resumen

Este artículo propone un marco para la gestión del uso de celebridades, con la intención de minimizar los riesgos y optimizar los resultados relativos al proceso de elección y uso de celebridades endosantes. Se presenta una revisión de la literatura nacional e internacional relevante al propósito del artículo, así como datos cuantitativos exploratorios recolectados de 4,5 mil brasileños, acerca de la percepción sobre celebridades endosantes en una serie de atributos. Los descubrimientos vuelven evidentes las diferencias de percepción de los grupos de celebridades analizados - general, deportes y fútbol (como subgrupo deportivo) -, indicando la necesidad de desarrollar y adoptar modelos de decisión sobre el uso del endoso de celebridades.

PALABRAS CLAVE: DEPORTE • ENDOSO DE CELEBRIDADES • MARCA ENDOSADA • MARKETING • COMUNICACIÓN 
$\mathrm{H}$ á muito se sabe que o uso de testemunhos de pessoas comuns pode aumentar as chances de identificação e empatia por parte dos consumidores em relação a uma determinada campanha publicitária e, por conseguinte, aumentar as intenções de compra do produto/marca anunciado (Ohanian, 1990). Há, também, uma crença comum por parte tanto dos praticantes de marketing, quanto das agências de publicidade, de que o uso de pessoas famosas e bem conhecidas por parte do público - sejam elas artistas, músicos ou atletas - surte um efeito ainda maior que os testemunhos, "carimbando" a campanha com um selo de garantira de resultados.

\section{ENDOSSO DE CELEBRIDADES}

Será que o uso de celebridades em comunicação no Brasil é tão elevado que mereça ser objeto de estudos acadêmicos mais sofisticados? Ou será que pesquisadores e profissionais de marketing e comunicação fazem um tipo de consumo de mídia que os leva a prestar mais atenção ou a receber mais mensagens com esse viés?

Respondendo à primeira indagação, um estudo realizado pela Itumeo entre 2008 e $2010^{1}$ apontou que $25 \%$ das campanhas veiculadas no Brasil utilizavam celebridades, o que, por si só, revela a importância do assunto. A maioria das campanhas foi veiculada pelas maiores empresas do Brasil, com as maiores verbas de marketing em seus respectivos setores, nos maiores grupos de mídia nacionais, impactando significativamente não só o consumidor, mas a sociedade brasileira em geral, no que diz respeito à exposição de suas marcas e produtos.

Vários pesquisadores já se debruçaram sobre o tema em nível internacional, procurando demonstrar a relevância do uso de celebridades a partir de vieses específicos (Spry, Pappu e Cornwell; 2011; Patel, 2009; Agrawal e Kamakura, 1995; Kahtri, 2006; Al-Smadi, 2006; Mccraken, 1989; Halonen-Knight e Hurmerinta, 2010; Mohammad e Mohammad, 2011; Ranjbarian, Shekarchizade e Momeni, 2010; Ohanian, 1990; Shimp, 2002; entre outros). No plano das pesquisas e publicações nacionais, contudo, encontramos poucas abordagens, em sua maioria de cunho teórico-conceitual (Freire, Behling e Reinert, 2010; Andrade, Mazzon e Katz, 2006; Poliano e Freire, 2011; Salinas e Freire, 2011; Andrade, 2008). Vamos, portanto, tratar daqueles que consideramos mais significativos para a discussão que intentamos promover neste artigo.

1 Ver: Empresa mede a escolha de celebridades para campanhas. Disponível em: <http://exame.abril. com.br/marketing/noticias/empresa-mede-a-escolha-de-celebridades-para-campanhas $>$. Acesso em: 25/05/2011. Ver também: <http://www.ilumeobrasil.com.br/mais_resultados.htm>. 


\section{ASPECTOS RELEVANTES ACERCA DA INFLUÊNCIA DO ENDOSSO DE CELEBRIDADES ÀS MARCAS}

Tendo certeza da relevância contemporânea do tema, partimos para uma revisão da literatura acadêmica nacional e internacional acerca do endosso de celebridades. A melhor forma de compreender o conjunto mais importante das propostas acadêmicas é deixar de lado o olhar cronológico e colocá-las em um continuum evolutivo, que faça sentido em termos de onde queremos chegar com o presente estudo. Para isso, serão utilizados basicamente dois critérios:

- quantidade de variáveis em questão;

- abrangência dos níveis de análise e adaptabilidade ao framework de planejamento, gestão e controle do uso de celebridades, proposto neste estudo.

As discussões mais básicas em relação ao uso de celebridades em comunicação são de Khatri (2006), que tratava a personalidade como endorser do produto anunciado: pessoa famosa com tamanha autoridade em relação a um assunto que "emprestaria" para o produto a credibilidade necessária para persuadir o consumidor a comprá-la. Segundo o autor, a credibilidade da fonte se destaca como importante fator de aceitação de influência, tendo como resultado o aumento de vendas.

Ampliando significativamente o escopo de análise, Ohanian (1990) desenvolveu uma escala para avaliar a credibilidade da celebridade a partir de três dimensões: confiabilidade, atratividade e experiência, partindo do conceito de credibilidade da fonte que, segundo o autor, já vinha sendo discutido desde 1960 por vários outros estudiosos dos campos da psicologia, da comunicação, do marketing e da propaganda (Ohanian, 1990, p. 48-49), porém, sem a confirmação do construto em termos de confiabilidade e validade estatísticas.

Shimp (2002) promove uma ampliação da perspectiva de Ohanian (1990) ao acrescentar mais duas dimensões que devem ser analisadas. Para ele, os anunciantes utilizam os atributos que determinada personalidade possui para transferi-lo para o seu produto e, em alguns casos, o consumidor chega a comprar determinadas marcas por gostar do endossante. O autor também aponta o lado negativo do uso de celebridades, por conta do trajeto de vida escolhido por elas, o que pode fazer com que certas atitudes sejam amplamente veiculadas na mídia, causando diferentes interpretações e reações, podendo - num determinado momento - afetar a imagem da marca endossada pela celebridade (Shimp, 2002, p. 270-272).

Trata-se de uma evolução do pensamento, pois o autor coloca credibilidade, atratividade e experiência como atributos importantes, mas não os únicos. A partir desse pensamento, ele propõe o modelo tears (do inglês: Trustwothiness, Expertise, Attractiveness, Respect, Similarity) dividido em cinco categorias de análise (Shimp, 2002):

- credibilidade/confiabilidade;

- expertise; 
- atratividade;

- respeito;

- afinidade.

Trata-se de um salto conceitual com consequências práticas muito claras, podendo-se passar a pensar mais livremente na contratação de celebridades, sem as amarras do "especialista no assunto". Uma marca esportiva não estaria fadada a contratar somente atletas para suas campanhas, podendo pensar em outras celebridades que também consigam transmitir atributos interessantes para a marca ou produto.

Na mesma linha, Patel (2009) desenvolve um modelo que contempla sete atributos (características inerentes ou percebidas na celebridade) e sete questões práticas a se ter em mente no momento da contratação (separação didática proposta pelos autores deste artigo):

Quadro 1: Adaptação do modelo de Patel (2009)

\begin{tabular}{|l|l|}
\hline \multicolumn{1}{|c|}{ Atributos } & \multicolumn{1}{c|}{ Questões práticas: } \\
\hline 1. Credibilidade & 1. Adequação à ideia da propaganda \\
2. Profissão & 2. Outros endossos \\
3. Atratividade física & 3. Disponibilidade \\
4. Celebridade como usuária da marca & 4. Custo de contratação \\
5. Valores & 5. Afinidade entre celebridade e produto \\
6. Riscos controversos & 6. Apelo regional \\
7. Popularidade & 7. Celebridade e público-alvo \\
\hline
\end{tabular}

Fonte: Desenvolvido pelos autores

Os modelos de Shimp (2002) e Patel (2009) trazem evoluções em relação ao pensamento dos autores anteriormente apresentados, mas propondo somente que todos esses âmbitos de análise das celebridades têm função de fazer a comunicação alavancar as vendas e valorizar a marca no mercado.

Quadro 2: Análise das celebridades como aspecto intermediário do framewok de gestão do endosso de celebridades

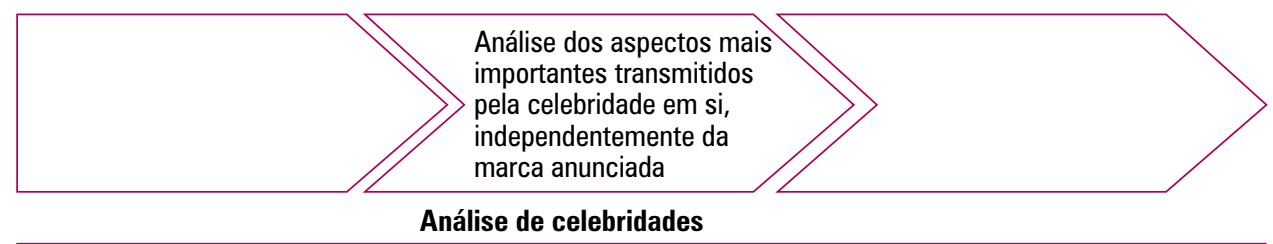

Fonte: Desenvolvido pelos autores 
Segundo Yanaze, Freire e Senise (2010), p. 73), “essa simplificação, além de antiga, desconsidera diversos estudos e pesquisas sobre o processo de comunicação e de decisão de compra”. Por isso mesmo, os estudos apresentados anteriormente com foco na análise das celebridades são parte de um problema cuja investigação é mais ampla, como procuraremos demonstrar.

Alguns autores já deixaram de ver a celebridade somente como endosso de credibilidade que leva à venda. Segundo Spry, Pappu e Cornwell (2011), o endosso de celebridade influencia a eficácia da publicidade, o reconhecimento da marca, o recall da marca, as intenções de compra e o comportamento de compra.

Se o endosso de celebridades é utilizado prioritariamente como estratégia de comunicação com o mercado, a complexidade dos níveis de influência da comunicação encontrados em Yanaze (2011) pode ser empregada não somente para analisar o impacto do uso de celebridades em relação a marcas e produtos. Pode, também, antecipar esse impacto por meio do refinamento do estabelecimento dos objetivos de comunicação, encarando esta última como um processo que leva a marca ou o produto do desconhecimento completo a um possível alto nível de interação e envolvimento com os consumidores e a sociedade em geral.

Yanaze (2011) entende que o profissional de marketing e comunicação deve demonstrar claramente como cada objetivo de comunicação pode contribuir para os objetivos de negócio, em termos tanto mercadológicos, quanto institucionais, raciocínio essencial para o entendimento da proposta deste artigo.

\section{Quadro 3: Possíveis objetivos de comunicação de uma organização para seus diversos stakeholders, partindo do entendimento da comunicação como um processo}

\section{A comunicação como um processo}

01. Despertar consciência - As necessidades são inerentes aos seres humanos, mas, em muitos casos, algumas delas não estão no nível do sentido ou da percepção. Despertar certo grau de consciência das necessidades e carências, relacionadas com o objeto da comunicação, deve ser a primeira etapa do processo de comunicação.

02. Chamar atenção - A pessoa que já tenha certo grau de consciência de suas necessidades e carências, certamente terá sua atenção despertada com maior facilidade. Se o receptor não tiver nenhuma consciência da relevância da mensagem para ela, o processo se extingue na atenção.

03. Suscitar interesse - A consciência prévia direciona a atenção do indivíduo, despertando interesse.

04. Proporcionar conhecimento - 0 receptor interessado está pronto para receber uma informação mais detalhada, ampliando seus conhecimentos sobre o objeto da comunicação.

05. Garantir identificação/empatia - Por meio das características e das possibilidades de percepção do receptor - seu vocabulário literário e gráfico e perfil psicossociodemográfico - dá-se a identificação e o estabelecimento de uma relação de empatia. 
06. Criar desejo e/ou suscitar expectativa - Lançar mão de elementos que criem desejo de compra ou suscitem expectativa favoráveis à marca.

07. Conseguir a preferência - Como a empresa não está sozinha no mercado, o processo exige argumentos que garantam a preferência do indivíduo, a despeito dos concorrentes.

08. Levar à decisão - Depois de conseguir a preferência do receptor, a comunicação deverá levá-lo a se decidir pela compra ou a realizar aquilo que o objeto da comunicação preconiza.

09. Efetivar a ação - Muitas vezes, a tomada de decisão não é imediatamente seguida da ação objetivada pela comunicação. A comunicação deve identificar previamente fatores de atraso e procurar minimizar seus efeitos ou valorizar outros fatores que levem seu público-alvo à ação. Trata-se da principal consagração de todo esforço de marketing. Mas não é a única nem a final.

10. Garantir e manter a satisfação pós-ação - 0s serviços de atendimento ao cliente (SACs), anúncios e mensagens diretas, que elogiam a decisão de compra (ou da ação) e que ratificam o bom gosto e a inteligência da preferência pela marca (ou da realização), geralmente contribuem para a redução da dissonância cognitiva (Festinger, 1957), ajudando na manutenção de certo nível de satisfação.

11. Estabelecer interação - Estabelecer um fluxo contínuo, de duas mãos, com seus interlocutores, bem como processos consistentes de melhoria de relações com seus públicos.

12. Obter fidelidade - Identificar as razões de fidelização ou detração e estudar como otimizá-las ou revertê-las.

13. Gerar disseminação de informações pelos interlocutores - Formação de agentes geradores e disseminadores de comunicação positiva, a partir dos públicos-alvo. Estabelecimento de estratégias de comunicação para incentivar seus clientes a emitir seus sentimentos e compartilhar suas experiências positivas com outras pessoas de suas relações

Fonte: Adaptado de Yanaze (2011)

O benefício de pensar a comunicação como um processo e sistematizar os catorze objetivos possíveis é ajudar o profissional a gerenciar melhor os esforços de comunicação a partir de uma premissa básica: cada objetivo pode ser quantificado e transformado em indicador de sucesso da comunicação (Yanaze; Freire; Senise, 2010).

O fato de inserir o uso de celebridades na perspectiva do marketing accountability dá início a uma discussão muito mais sofisticada, pois, afinal de contas, sem analisar esses aspectos, o valor pago pelo uso da imagem de uma determinada celebridade fica, equivocadamente, na ordem do subjetivo. Investidores e diretores financeiros podem e devem questionar contratações milionárias de celebridades para campanhas de comunicação e a área de comunicação de marketing deve trazer para si a responsabilidade de decisão acerca do uso ou não de celebridades e da mensuração dos possíveis resultados - como forma de angariar credibilidade enquanto departamento ou função gerencial.

Não menos importante, porém, é a percepção dos decisores sobre o uso das celebridades - normalmente, diretores de marketing e publicitários em agências. É preciso entender a partir de quais critérios as decisões sobre celebridades são tomadas atualmente. Não só identificar o uso de ferramentas, mas lógica da tomada de decisão, os raciocínios e justificativas por trás dos discursos, 
as crenças que os levam a depositar confiança em alguma celebridade, mesmo que não sejam baseadas em dados empíricos. Dessa forma, é possível comparar a percepção subjetiva dos profissionais de marketing e comunicação com a percepção da população em relação à celebridade e, ainda mais a fundo, "se" e "como" ela ajuda a alcançar os objetivos de comunicação.

Quadro 4: Análise das celebridades e seu alinhamento aos objetivos de comunicação como aspecto intermediário do framewok de gestão do endosso de celebridades

\begin{tabular}{|l|l|l|l|l|l|l|l|l|l|l}
\hline $\begin{array}{l}\text { Análise dos aspectos } \\
\text { mais importantes } \\
\text { transmitidos pela celebridade } \\
\text { em si, independentemente } \\
\text { da marca anunciada }\end{array}$ & $\begin{array}{l}\text { Quais celebridades } \\
\text { podem ajudar ou atrapalhar } \\
\text { a empresa a atingir } \\
\text { determinados objetivos } \\
\text { de comunicação }\end{array}$ \\
\hline Análise de celebridades & Objetivos de comunicação \\
\hline
\end{tabular}

Fonte: Desenvolvido pelos autores

Quadro 5: Refinamento dos drivers utilizados para decisão por parte dos profissionais de marketing como aspecto inicial do framewok de gestão do endosso de celebridades

\begin{tabular}{|c|c|c|}
\hline $\begin{array}{l}\text { Discurso dos gestores } \\
\text { de comunicação sobre } \\
\text { os drivers de tomada } \\
\text { de decisão }\end{array}$ & $\begin{array}{l}\text { Análise dos aspectos } \\
\text { mais importantes } \\
\text { transmitidos pela celebridad } \\
\text { em si, independentemente } \\
\text { da marca anunciada }\end{array}$ & $\begin{array}{l}\text { Quais celebridades } \\
\text { podem ajudar ou atrapalha } \\
\text { a empresa a atingir } \\
\text { determinados objetivos } \\
\text { de comunicação }\end{array}$ \\
\hline Profissionais de marketing & Análise de celebridades & tivos de comunicação \\
\hline
\end{tabular}

Fonte: Desenvolvido pelos autores

Ao falar em percepção subjetiva, a ideia não é denegrir a inteligência ou o profissionalismo dos tomadores de decisão sem uma investigação mais profunda. Trata-se de assumir que cada indivíduo possui percepções diferentes acerca das celebridades, provavelmente por conta dos antecedentes relacionados a essa decisão (o que merece estudos a esse respeito), em termos de seus valores, estilo de vida, consumo de mídia etc. A distância entre a visão dos profissionais de marketing e comunicação das empresas e os publicitários em relação à visão do público geral é inevitável, o que pode reduzir a eficácia dos objetivos de comunicação propostos ou, até mesmo, gerar problemas futuros, em vez de resolvê-los.

Estudos nessa área podem auxiliar na redução desse gap, dessa lacuna, ou seja, reduzir o risco de uma escolha equivocada e apresentar os principais aspectos que devem ser considerados, mensurados e geridos por parte dos profissionais 
de marketing e comunicação. A razão é que o endosso de celebridades pode influenciar não somente a intenção de compra, o awareness ou o recall de marca, mas, fundamentalmente, a percepção de qualidade e valor de marca, sua reputação e os atributos que a sustentam institucionalmente. Nesse sentido, o dano de uma escolha sem critérios definidos e sem análise prévia e monitoramento das percepções pode ser catastrófico.

Essa visão está muito alinhada com os estudos de mensuração de retorno de investimento no Brasil (Yanaze, Freire, Senise, 2010) que entendem mensuração como um conjunto sistemático de observações redutoras da incerteza e do risco, por meio de métodos bem construídos (Hubbard, 2008, p. 25). O entendimento evolutivo dos estudos apresentados neste artigo e a proposta de modelo abrangente de análise do tema pode ajudar as organizações a elaborarem estudos e lógicas de tomada de decisão que reduzam o risco de uma escolha equivocada.

Trata-se de um framework conceitual, um modelo genérico e não de uma fórmula-padrão de utilização de dados empíricos na tomada de decisão em relação a celebridades em comunicação. Isso porque a realidade de cada marca bem como as suas necessidades comunicacionais - é muito peculiar, tornando sempre limitadas e presunçosas quaisquer tentativas de generalização.

\section{ANALISANDO A PERCEPÇÃO DOS BRASILEIROS ACERCA DAS CELEBRIDADES DO ESPORTE}

Como forma de explorar um pouco mais o assunto, vale entender como as celebridades são percebidas pela população brasileira. Os atributos pesquisados nesta coleta primária foram definidos, como dito anteriormente, a partir de consulta a vários profissionais de marketing e comunicação de empresas e agências que fazem uso constante de endosso de celebridades.

A primeira pergunta do questionário referia-se ao fato de os pesquisados conhecerem/lembrarem ou não a celebridade que aparecia em uma foto. A ela, seguiam-se treze escalas em diferencial semântico em sete níveis, versando sobre os atributos levantados entre os profissionais de marketing e comunicação. Para efeito de análise agrupamos as duas respostas mais evidentes do diferencial semântico, ao estilo top 2 box. Por exemplo, para o atributo beleza, os percentuais apresentados no estudo revelam o somatório entre as frequências de respostas entre os níveis 1 e 2 (para aqueles que são considerados bonitos) e 6 e 7 (para os considerados feios). Ao final, após responder aos treze atributos, o profissional ainda declarava quantas e quais marcas se lembrava de ter visto com o endosso da celebridade que aparecia na foto.

Nesse levantamento quantitativo, foram entrevistadas cerca de 45 mil pessoas em todo o Brasil, procurando avaliar a percepção dos respondentes acerca de 
130 celebridades brasileiras, sendo que dezessete destas eram do setor de esportes. A pesquisa de campo se deu entre junho e julho de 2011. Foi executada uma amostra aleatória, que resultou num perfil geral composto de homens e mulheres, acima de catorze anos de idade, distribuídos entre todas as classes econômicas do Brasil, porém, sem modelagem probabilística.

Para os propósitos do presente estudo, separamos as dezessete celebridades esportivas e as comparamos com as celebridades de outros ramos (artistas, modelos, apresentadores, músicos, humoristas etc.). Promovemos, ainda, um corte específico no que diz respeito às celebridades do futebol. Trata-se de um esporte extremamente conectado à cultura dos brasileiros e que recebe ampla cobertura midiática não somente durante as partidas. Ele propicia, assim, maior contribuição acerca da adequação do uso de celebridades em termos de congruência com a marca e com o público geral ou segmentado.

Os resultados mais significativos foram evidenciados, ocultando-se do estudo os que não revelavam grandes aprendizados ou que pareceram apresentar apenas obviedades, pelo julgamento dos autores. Das treze escalas de atributos, portanto, trataremos de apenas três na comparação entre a percepção das celebridades do esporte em geral e as celebridades específicas do futebol.

Comparando as personalidades relacionadas ao futebol com personalidades de outros esportes, percebe-se que os atletas desvinculados do futebol sobressaem principalmente nos atributos confiabilidade e inteligência, ao passo que uma pequena diferença positiva destaca positivamente as celebridades do futebol: a percepção de popularidade.

Quadro 6: Celebridades do esporte em geral X Celebridades do futebol Atributos mais evidentes

\begin{tabular}{|l|c|c|c|c|}
\hline \multicolumn{1}{|c|}{ ATRIBUTO } & \multicolumn{2}{c|}{$\begin{array}{c}\text { MÉDIA ESPORTE } \\
\text { (sem futebol) }\end{array}$} & \multicolumn{2}{c|}{ MÉDIA FUTEBOL } \\
\hline Confiável / não confiável & $49 \%$ & $7 \%$ & $43 \%$ & $8 \%$ \\
\hline Inteligente / não inteligente & $57 \%$ & $5 \%$ & $51 \%$ & $7 \%$ \\
\hline Popular / elitizado & $52 \%$ & $10 \%$ & $54 \%$ & $9 \%$ \\
\hline
\end{tabular}

Fonte: Desenvolvido pelos autores

Um dos pontos possíveis que devemos levar em conta para começarmos a entender esses resultados é considerar que há um maior envolvimento dos brasileiros com o futebol do que com outros esportes. Como é mais comum acompanhar os jogadores de futebol nos jogos na mídia, a inclinação à atenção seria mais forte em relação a algum outro atleta que representa o Brasil internacionalmente, mas que não tem o mesmo nível de exposição na mídia. De 
qualquer forma, esse tipo de análise é fundamental para gerentes de marketing e comunicação terem maior embasamento sobre a percepção das pessoas acerca de uma celebridade esportiva, quando da escolha de um endossante para as marcas e produtos de suas empresas.

Esse alto envolvimento emocional com o futebol no país também pode ter relação com resultados da comparação entre celebridades do esporte em geral e celebridades do futebol. Por exemplo, a percepção de menos inteligência e confiabilidade que a população tem dos jogadores provavelmente está relacionada a uma identificação de trajetória de vida padronizada, muito próxima de um estereótipo (jogadores que nasceram em situação socioeconômica precária e ganharam muito dinheiro em pouco tempo, o que os leva a se deslumbrarem com a fama). Outro ponto possível que sustentaria essa percepção remete à maneira como os jogadores são apresentados na mídia: em entrevistas que apresentam níveis de discurso nem sempre seguindo as regras cultas da língua e, até mesmo, em notícias polêmicas e espetaculosas sobre suas vidas pessoais. Esses dois pontos comporiam a perspectiva do estereótipo de Schaff (1974), que nada mais é que uma forma rápida e eficiente de se interpretar a realidade.

Apesar disso, as celebridades do futebol se destacam em um atributo que é essencial para empresas: popularidade (no sentido de serem "do povo"). Nesse ponto, é importante atentar para o fato de que é o contexto cultural citado anteriormente que pode estar influenciando a percepção acerca dos jogadores e que esse contexto pode mudar num determinado espaço de tempo. Fatores como a Olimpíada de 2016 no Brasil e a ascensão de renda e possibilidades de lazer das camadas mais populares podem provocar a difusão de esportes como tênis e natação, que são restritos a uma pequena parte da população atualmente e que estão fora do estereótipo relacionado ao futebol. Ou seja, é possível que a postura de determinadas celebridades não mude ao longo do tempo, mas, mesmo assim, pode haver mudança na sua imagem percebida, já que os indivíduos na sociedade estão se transformando continuamente devido a inúmeros fatores.

Entretanto, quando comparamos os resultados das celebridades em geral com as do esporte - considerando todos eles, ou seja, incluindo o futebol -, há mudanças nos atributos discriminantes dos grupos. Para efeito de concentração da análise, foram escolhidos os atributos com maior lacuna de percepção por parte dos respondentes do estudo: beleza, modernidade, sedução, bom gosto ao se vestir e brasilidade.

Alguns resultados podem soar bastante lógicos do ponto de vista da percepção geral do público como, por exemplo, o atributo beleza. Ocorre que, entre as celebridades esportivas, figuravam não somente atletas que já endossaram várias marcas e produtos, mas que já fizeram ensaios fotográficos, ao passo que, entre as celebridades em geral, há boa presença de comediantes, apresentado- 
res de programas de televisão e artistas que poderiam pesar negativamente nesse quesito. Um atributo correlacionado com beleza é a sedução. Numa observação mais criteriosa, contudo, percebemos que há celebridades que são julgadas de maneira diferente. Há tanto celebridades consideradas bonitas, porém pouco sedutoras, quanto celebridades consideradas sedutoras, porém não bonitas aos olhos dos respondentes.

\section{Quadro 7: Celebridades em geral X Celebridades do esporte (incluindo o futebol) - Atributos mais evidentes}

\begin{tabular}{|l|c|c|c|c|}
\hline \multicolumn{1}{|c|}{ ATRIBUTO } & \multicolumn{2}{c|}{$\begin{array}{c}\text { MÉDIA } \\
\text { CELEBRIDADES }\end{array}$} & \multicolumn{2}{c|}{$\begin{array}{c}\text { MÉDIA ESPORTE } \\
\text { (com futebol) }\end{array}$} \\
\hline Lindo / feio & $47 \%$ & $11 \%$ & $27 \%$ & $21 \%$ \\
\hline Moderno / tradicional & $47 \%$ & $12 \%$ & $27 \%$ & $13 \%$ \\
\hline Sedutor / não sedutor & $47 \%$ & $12 \%$ & $27 \%$ & $13 \%$ \\
\hline Se veste bem / se veste mal & $47 \%$ & $12 \%$ & $27 \%$ & $13 \%$ \\
\hline Transmite brasilidade / não transmite brasilidade & $62 \%$ & $7 \%$ & $70 \%$ & $4 \%$ \\
\hline
\end{tabular}

Fonte: Desenvolvido pelos autores.

Beleza, sedução e bom gosto para se vestir, assim como alguns atributos não apresentados neste estudo, podem ser considerados atributos de um mesmo fator: beleza e preocupação estética. Outro fator relevante é a personalidade. Podemos perceber que as celebridades em geral são consideradas mais modernas do que as celebridades do mundo esportivo. Na outra ponta, os atletas famosos são considerados mais tradicionais do que as celebridades em geral.

Mas é no último atributo apresentado que se nota uma inversão significativa: os atletas possuem maior congruência com o quesito "brasilidade". Ou seja, para marcas que querem emprestar das celebridades o fato de carregarem uma imagem arquetípica do que seja ser brasileiro, é relevante considerar os atletas famosos em vez das celebridades em geral.

Vale ressaltar que qualquer tipo de raciocínio apresentado merece cuidados. Os resultados não consideraram nenhum tipo de marca ou setor. Portanto, não há avaliação adequada da congruência entre as celebridades e determinadas marcas. O propósito dos autores, ao apresentar as percepções dos respondentes era tão- somente demonstrar o quão diferentes elas podem ser, no geral, no setor específico de atuação e individualmente.

Uma marca que pretende gerar identificação entre o público e sua mensagem deve levar em conta essa complexidade, tentando entender quais aspectos da imagem percebida das celebridades são essenciais, quais são mais congruentes e, portanto, possuem menos chances de gerar ruído na comunicação e 
quais têm mais potencial de gerar bons resultados. Ousamos dizer que se trata de um "xadrez dinâmico", já que a estratégia de jogo não depende somente da faceta das peças (celebridades e marcas), mas do entendimento do próprio tabuleiro em movimento (mudanças nas pessoas que percebem e julgam as celebridades e as marcas).

Há que se considerar a necessidade de acompanhamento contínuo da imagem das celebridades como ponto inicial de discussões estratégicas sobre as marcas. Peter Drucker já havia feito um alerta quanto à necessidade da mensuração para alcançar a excelência na gestão: "If you can't measure it, you can't manage it".

Isso nos leva ao ponto que vai garantir um processo de melhoria e aproveitamento contínuo dos resultados advindos do uso de celebridades a favor da marca e dos produtos endossados, precavendo gestores de marketing e comunicação do maior erro que se pode cometer nesse tipo de projeto: começar o raciocínio a partir de uma exigência de resultados, mesmo depois de a escolha já ter sido feita. Não é necessário dizer que os infinitos relatórios recheados com uma série de números estará, rigorosamente, relacionando o resultado a nada que tenha sido planejado como objetivo factível e metas coerentes com a escolha do endossante.

Quadro 8: Framewok final da gestão do endosso de celebridades

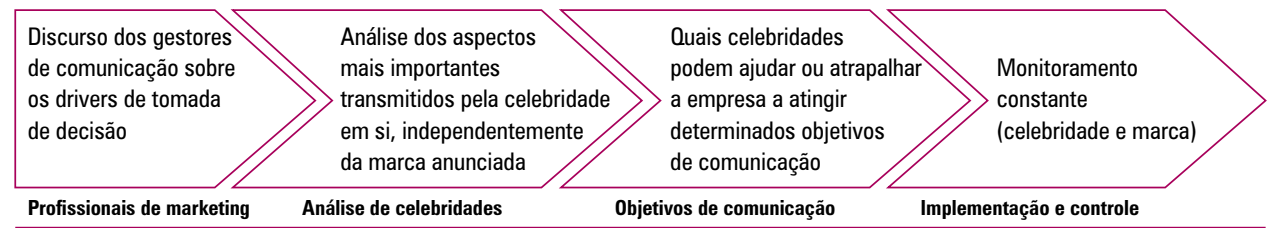

Fonte: Desenvolvido pelos autores

Um raciocínio inteligente e diferenciado acerca do processo de escolha de celebridades implicará boas medidas de desempenho, que vão se traduzir em resultados positivos e, principalmente, na certeza da redução dos riscos. Mensurando constantemente, o risco se tornará cada vez menor e a otimização do endosso, cada vez maior.

\section{CONSIDERAÇÕES FINAIS}

O presente artigo procurou evidenciar a importância de as organizações desenvolverem modelos de escolha, planejamento de uso, gestão e controle do endosso de celebridades, de tal forma que os riscos envolvidos sejam minimizados e que os resultados gerados por esse tipo de estratégia sejam otimizados. 
Partimos do estudo da literatura nacional e internacional existente e de impacto, optando por apresentar a revisão da literatura de acordo com critérios que auxiliaram o desenvolvimento do framework de gestão do uso de endosso de celebridades, em detrimento de uma apresentação cronológica desses estudos.

Procuramos evidenciar as diferentes percepções acerca das celebridades e o quanto elas podem estar distantes da percepção dos profissionais de marketing e comunicação envolvidos no processo de escolha e uso de celebridades. Para tanto, foram apresentados dados primários coletados em uma amostra aleatória de cerca de 4,5 mil brasileiros com mais de catorze anos de idade, residentes em vários estados do país, pertencentes aos diferentes extratos econômicos de nossa sociedade. Separamos as celebridades em dois grupos - celebridades em geral e celebridades do mundo esportivo - e um subgrupo com os atletas pertencentes ao futebol. A análise apresenta diferenças significativas na percepção dos atributos pesquisados, o que demonstra a importância de se pesquisar a população que será impactada pelas ações de endosso.

O estudo limitou-se a analisar a percepção das celebridades, não relacionando-as a qualquer tipo de endosso, desconsiderando o critério de congruência entre marca e celebridade. Esse entrave, não limita o desenvolvimento do modelo de gestão de endosso de celebridades, pois não influencia no framework proposto. Apresenta e evidencia, contudo, diferenças de percepção dos atributos relacionados às celebridades que os profissionais de marketing e comunicação usualmente procuram "emprestar" às marcas e aos produtos de suas empresas.

Há, no Brasil, carência de estudos mais completos acerca do tema, tanto do ponto de vista qualitativo - que pudessem aprofundar uma série de inquietações contemporâneas -, quanto de estudos de validação de hipóteses por meio de análises quantitativas multivariadas, que pudessem apontar linhas gerais de ação em termos de escolha de celebridades endossantes.

Pesquisadores brasileiros devem mergulhar no tema, procurando, por exemplo: entender as mudanças na percepção das celebridades ao longo do tempo e seu impacto na percepção da marca endossada; analisar web celebrities; compreender as diferenças entre os efeitos do endosso de celebridades nacionais e estrangeiras; aprofundar as questões pertinentes à tomada de decisão, como discutido no início do modelo proposto neste artigo.

Tanto o volume de marcas endossadas, quanto o de celebridades endossantes é significativo no Brasil e no mundo, impactando uma grande parcela não só de consumidores, mas a sociedade num sentido mais amplo. Estes e outros temas ainda devem ser explorados como forma de descortinamento das questões referentes ao endosso de celebridades. 


\section{REFERÊNCIAS}

AGRAWAL, Jagdish; KAMAKURA, Wagner A. The economic worth of celebrity endorses: an event study analysis. Journal of Marketing, v. 59, n. 3, p. 56-62, 1995.

AL-SMADI, Sami. The power of celebrity endorsement in brand choice behavior: an empirical study of consumer attitudes. The Journal of Accounting, Business, and Management, v. 13, 2006.

ANDRADE, Josmar. A fama como passaporte para a atenção: reflexões sobre o uso de celebridades na comunicação de marketing global. Internext, São Paulo, v. 3, n. 1, p. 16-38, jan.-jun. 2008.

ANDRADE, Josmar; MAZZON, J., KATZ, S. Você viu o vídeo do Ronaldinho? Uma reflexão a respeito da associação entre marcas e celebridades e 0 uso do marketing viral como ferramenta de comunicação de marketing. In: ENCONTRO NACIONAL DA ASSOCIAÇÃO NACIONAL DE PÓS-GRADUAÇÃO E PESQUISA EM ADMINISTRAÇÃO (EnANPAD), XXX, Rio de Janeiro, 2006. Anais... Rio de Janeiro: Anpad, 2006.

FESTINGER, Leon $A$ theory of cognitive dissonance. Palo Alto, CA: Stanford University Press: 1957.

FREIRE, Robson; BEHLING, Hans P; REINERT, Juliana. Endosso de celebridades: uma análise baseada na complementaridade de modelos teóricos. In: CONGRESSO DE CIÊNCIAS DA COMUNICAÇÃO DA REGIÃO SUL, XI, Novo Hamburgo, RS, 17 a 19 de maio de 2010. Anais... São Paulo: Intercom, 2010.

HUBBARD, Douglas W. Como mensurar qualquer coisa: encontrando valor do que é intangível nos negócios. Rio de Janeiro: Qualitymark, 2008.

KELLER, Kevin L.; MACHADO, Marcos. Gestão estratégica de marcas. São Paulo: Pearson Prentice-Hall, 2005.

KHATRI, Paul. Celebrity endorsement: a strategic promotion perspective. Indian Media Studies Journal, v. 1, n. 1, Jul.-Dec. 2006.

HALONEN-KNIGHT, Elina; HURMERINTA, Leila. Who endorses whom? Meanings transfer in celebrity endorsement. Journal of Product \& Brand Management, v. 19, n. 6, p. 452-460, 2010.

MOHAMMAD, O. AI Zoubi; MOHAMMAD, T. Bataineh. The effect of using celebrities in advertising on the buying decision: empirical study on students in Jarash Private University. American Journal of Scientific Research, n. 13, p. 59-70, 2011.

McCRAKEN, Grant. Who is the celebrity endorser? Cultural foundations of the endorsement process. Journal of Consumer Research, v. 16, n. 3, p. 954-961, Dec. 1989.

OHANIAN, Roobina. Construction and validation of a scale to measure celebrity endorsers' perceived expertise, trustworthiness, and attractiveness. Journal of Advertising, v. 19, n. 3, p. 39-52, 1990.

PATEL, Pankaj. Impact of celebrity endorsement on brand acceptance.The Icfai University Journal of Consumer Behavior, v. 4, n. 1, p. 36-45, 2009.

POLIANO, Manoella; FREIRE, Otávio. Como a utilização de celebridades é relevante na retenção da mensagem, impactando o comportamento do consumidor. In: PEREZ, Clotilde; TRINDADE, Eneus; (Org.). Como anda a publicidade? [II Pró-Pesq - Encontro Nacional de Pesquisadores em Publicidade e Propaganda]. Salto, SP: Editora Schoba, 2011. p. 841-853..

RANJBARIAN, Bahram; SHEKARCHIZADE, Zahra; MOMENI, Zahra. Celebrity endorser influence on attitude toward advertisements and brands. European Journal of Social Sciences, v. 13, n. 3, 2010.

SALINAS, Durval; FREIRE, Otávio. Comunicação com uso de celebridades: uma discussão do retorno de investimento. In: PEREZ, Clotilde; TRINDADE, Eneus (Org.). Como anda a publicidade? [II Pró-Pesq - Encontro Nacional de Pesquisadores em Publicidade e Propaganda]. Salto, SP: Editora Schoba, 2011. p. 854-866.

SCHAFF, Adam. Linguagem e conhecimento. Coimbra: Almedina, 1974.

SHIMP, Terence. Propaganda e promoção: aspectos complementares da comunicação integrada de marketing. 5. ed. Porto Alegre: Bookman, 2002.

SPRY, Amanda; PAPPU, Ravi; CORNWELL, T. Bettina. Celebrity endorsement, brand credibility and brand equity. European Journal of Marketing, v. 45, n. 6, p. 882-909, 2011.

YANAZE, Mitsuru; FREIRE, Otávio; SENISE, Diego. Retorno de investimentos em comunicação: avaliação e mensuração. São Caetano do Sul, SP: Editora Difusão, 2010.

YANAZE, Mitsuru. Gestão de marketing e comunicação: avanços e aplicações. 2. ed. São Paulo: Atlas, 2011.

Recebido em: 16.11.2011 / Aceito em: 28.11.2011 